\title{
Interdependence Among Creativity, Education, and Job Experience: A Municipal Company in Poland ${ }^{1}$
}

\author{
Marek Jabłoński²
}

Submitted: 10.05.2019. Accepted: 11.12.2019

\section{Abstract}

Purpose: The technological progress of production processes causes changes in the social structure of work, i.e. modifies the content of most, if not all, workplaces. In that respect, the identification of changes in the intensity of creativeness, the level of education, and the experience of employees in production processes and occupational tasks is a particularly important issue. The article investigates the interdependence among work creativity, education, and job experience of employees of one of the municipal companies operating in Poland.

Methodology: The study employs firm-level data covering over 2,200 observations. The study gathered data from three major internal sources of information: the scopes of responsibilities of organizational positions, personnel documentation regarding the individual level of education and professional experience, and the results of interviews with executive staff and employees on particular posts. The research proceedings base on document analysis, structured interviews, teamwork methods, and a classification technique.

Results: Research revealed that the complexity of work increased in the company. Jobs requiring higher levels of creativity are occupied by employees with relatively higher education. However, their average level of education in the analyzed period decreased as opposed to jobs that require relatively lower levels of creativity. The analysis of interdependence between creativity and job experience identified that there emerged a relatively shorter average job experience for employees who perform cognitive work. Moreover, the average job experience increased in the group of employees who perform routine manual and non-routine cognitive work.

Implications: The study refers to the job polarization issue by confirming the tendencies of labor markets. It also addresses issues concerned with technological progress, although they are not confirmed by research in this paper.

Originality/Value: The main contribution of the paper is the interesting dataset gathered. Furthermore, the paper addresses an interesting question where empirical research at the firm level is lacking, particularly municipal company.

Keywords: creativity, experience, education, municipal company

JEL: J24, J31, J40

\footnotetext{
1 The research for this article was financed by the Faculty of Commodity Science and Product Management of the Cracow University of Economics for the maintenance of research potential.

2 Cracow University of Economics, Department of Process Management, 27 Rakowicka St., 31-215 Cracow, Poland; e-mail: marekj@uek. krakow.pl; https://orcid.org/0000-0001-6922-0501.
} 


\section{Introduction}

Changes that happen in business generally relate to technological progress, which affects social and economic processes and results in the acceleration of knowledge-based economy sectors (Godin, 2006), product and processes innovations, business process, business models (Blaschke et al., 2017), and corporate structures (Brown et al., 2014; Snow et al., 2017). Such transformation processes in economies, sectors, and enterprises create demand for new employee skills (OECD, 2016) by favoring cognitive and social skills (Deming, 2017), which also result in changes in demand for specific types of jobs.

In analyses conducted in relation to labor markets, such changes are associated with the so-called polarization, which means that higher wage increases are achieved by employees in the upper and bottom income and skill segments, not those in the middle (Autor, 2015, p. 5). In this sense, changes that occur on the labor market - determined by technological progress in particular - also cause a relative increase in the productivity of employees with high and distinctive skills, responsible for abstract thinking, creativity, and problem-solving (Acemoglu and Autor, 2011). Moreover, representative research in this area shows that - under the influence of technological progress - the demand for experts and talented employees increases, especially in the field of artificial intelligence and information analysis. At the same time, the demand for some work performed so far by people - especially on the basis of average skills - decreases, because this work is increasingly automatized by computers, robots, and other digital technologies (Brynjolfsson and McAfee, 2014, p. 10). Furthermore, scientific research confirms that modern technologies such as digital technologies, robotics, and artificial intelligence penetrate production processes in many countries. Moreover, scholars show that the technological progress of production processes reduces the production costs in which human work is applied while increasing the number of new, more complex tasks (Acemoglu and Restrepo, 2016). Generally, the technological progress of production processes results in the change in the content of most, if not all, workplaces. In that respect, the identification of changes in the intensity of creativeness, the level of education, and the experience of employees in production processes and occupational tasks is a particularly important issue.

Therefore, the article examines the change in the share of job types that require different levels of creativity and investigates differences in the level of education and experience of employees in relation to specific task types in one of the municipal companies in Poland. The study employs firm-level data covering 2,309 job placement observations obtained from two time points: end of 2009 - 1,137 observations; end of 
2018 - 1,172 observations. The research refers to municipal enterprises and, therefore, indirectly concerns the public sector, which provides public infrastructure regarded as the public intermediate input (Altenburg, 1987; Suga and Tawada, 2007).

\section{Theoretical Background}

Creativity used in the production process is always indicated as the key aspect that enables the development of enterprises and determines the work difficulty (Batey, 2012). Creativity is especially important in terms of the knowledge-based economy, particularly management staff competencies (Kupczyk, 2014). The literature review indicates that creativity has been the subject of research for several decades. Nevertheless, there is no consensus on what creativity is and how to measure it. However, the researchers agree that - due to its complex nature - creativity concerns novelty usefulness, i.e. the production of novel and useful responses; Batey, 2012; Runco and Jaeger, 2012). As a multifaceted phenomenon, creativity involves cognitive, personality, and environmental components (Lemons, 2011; Batey, 2012). In that respect, creativity is the ability to create new, valuable ideas, and it may be considered a combination of two elements: conceptual and operational. The former is essential in the development of new methods, products, and concepts, while the latter is used in selecting and implementing the results of conceptual creativity in practice (Tomczyk-Horyń and Knosala, 2014).

Although creativity is the subject of research for a long time (Batey, 2012), until the 1950s, it was studied as an attribute of talented individuals and interpreted as an exceptional process (Barbot et al., 2011). The new approach that constituted the modern interest in creativity began in the second half of the 1950s (Bode and Villar, 2017; Funke, 2009). It basically resulted from the work of Guilford (1950), who emphasized the necessity of in-depth and detailed studies on creativity. Generally, since then, creativity has been viewed as a feature of the general population that can be measured and developed (Barbot et al., 2011, p. 124). Research on creativity focused first on individuals and differences in creative abilities and personality. Then, temporary states were taken into account as preceding variables, along with dyads and working groups interpreted as creative actors. With time, this approach focused on actors, supplemented with the study of the influence of context on creativity (Zhou and Hoever, 2014).

Basing on the review of the literature on creativity measurement tools, we may indicate four approaches: process, person, product, and press (Said-Metwaly et al., 2017; Barbot et al., 2011). The process approach in creativity measurement focuses on cogni- 
tive processes and structures or skills associated with creativity. This approach has the advantages of common usability, high reliability, and normalized criteria for range interpretation; but it also has some weaknesses, including the limited scope of measurement, conflicting evidence for validity, and bias due to scoring and sample size. The person approach relies on using self-report questionnaires that identify personality traits or creative achievements. It applies a set of distinctive personality traits for creative individuals like attraction to complexity, high energy, behavioral flexibility, intuition, emotional variability, self-esteem, risk-taking, perseverance, independence, introversion, social poise, and tolerance. The product-based assessment of creativity focuses on rating individuals' creative products in different areas, such as writing, art, music, science, and mathematics. In creativity measurement, subjects receive tasks to create something, and then experts in the field are asked to rate the level of creativity of each product on a Likert scale, by comparing them against each other. The press approach is based on the assumption that there is an indirect relationship between creativity and work environment, so situational factors affect creativity on an individual, organizational, and cultural level (Said-Metwaly et al., 2017).

However, referring to the contemporary discourse in the field of creativity, we should pay attention to Florida's research $(2002$; 2014) who questioned the conventional approach of economists to measure human capital by stressing that, "it is more important to measure what people do, not what they learn" (Mellander and Florida, 2011, p. 639). Moreover, Florida analyzed the definition of creativity, including economic (Andersson, 2011, p. 14) and psychological approaches (Amabile, 2012, p 1), to conclude that the latter is close to what labor economists described as cognitive and non-cognitive skills (Bode and Villar, 2017). On that basis, the current debate on creativity follows Florida's terminology of the creative class, which focuses on two main issues. The first one concentrates on factors of creative class spatial distribution, like universities and other service amenities (Glaeser et al., 2001; Shapiro, 2006), tolerance, and openness (Florida, 2002). The other issue concerns the measurement of human capital, which promotes an approach that - in terms of outcomes for regional development - a lower rank should be attached to the measurement of educational achievements, while it should be used more in occupational-based measures (Florida, 2002; Markusen, 2004; Marlet and van Woerkens, 2004; Mellander and Florida, 2011). Although, the results of the research conducted within this issue are ambiguous. Hence, some studies prove that the creative class measure exceeds the educational attainment measure (Boschma and Fritsch, 2009; Marrocu and Paci, 2012; Mcgranahan and Wojan, 2007; Mellander and Florida, 2011). Meanwhile, other research presents the opposite findings (Glaeser, 2005; Donegan et al., 2008). Moreover, researchers investigate the interdependence between the labor market outcomes and personal traits, in particular the correlation 
between wages, education, occupational tasks, and creativity perceived as cognitive and non-cognitive skills. Cawley, Heckman and Vytlacil (2001), along with Heckman, Stixrud, and Urzua (2006) find that cognitive and noncognitive skills explain wages through educational attainment, although they still question their direct interdependence. In that respect, Heckman et al. (2014) suggest that earlier research might overestimate the direct effect of noncognitive skills on wages.

Noteworthy, earlier studies focus on the analysis of differences in the so-called cognitive abilities and their impact on economic results (Leuven et al., 2004; Autor et al., 2003; Hanushek and Woessmann, 2009; Blau and Kahn, 2001; Devroye and Freeman, 2001). However, newer research focuses on the identification of "types of knowledge." For instance, Gabe and Abel (2011) analyze a diversified pattern of job ads in the USA in relation to the average profession by combining different knowledge requirements with the existence of clusters of employment in metropolitan areas. Other studies focus on basic skills, such as the ability to innovate or be creative. In that respect, Florida (2002; 2014) links the economic results of the metropolitan area with the presence of a "creative class," whose representatives with basic creative knowledge will ultimately stimulate economic growth. However, the basic idea of the creative class, says little about the type of knowledge that is itself the basis of "creativity."

Moreover, research identified a change in these personality traits over time (Bravermann, 1998; Machin and Van Reenan, 1998; Kremer and Maskin, 1996). In this case, a different classification was used in both positions, in relation to which the change in skills was diagnosed and the classification of skills. For particular research purposes, individual occupational groups are arbitrarily qualified for specific skill levels, which means that aggregated classifications of occupations and work positions do not always reflect changes in the content of the job (Bravermann, 1998). For example, labor market analyses of productive and non-productive workers arbitrarily assume that the former had higher while the latter lower levels of skills (Machin and Van Reenan, 1998). Similarly, positions qualified as white-collar were arbitrarily considered as requiring higher skill levels than blue-collar (Kremer and Maskin, 1996).

In response to the above controversies Autor, Levy, and Murnane propose the division of tasks on the basis of work content (Autor et al., 2003). This classification is used in studies on the impact of technical progress on the task composition of human employment, employment polarization, and the estimation of the potential scope of automation (Terzidis et al., 2017; Coelli and Borland, 2016; Goos and Manning, 2007; Autor et al., 2006; Autor and Handel, 2013; Goos et al., 2010). This typology conceptualizes each occupation as a series of tasks, which determine the necessary skills possessed by 
employees. Therefore, terms like "tasks" and "skills" are used interchangeably, depending on whether authors refer to an occupation or an employee. Moreover, this approach considers the innovativeness of tasks, which are routine, non-routine, problem-solving, and those requiring interpersonal adaptability; according to the typology (Autor and Acemoglu, 2011, p. 1076-1079), especially the tasks distinguished between routine tasks (including manual and cognitive) and nonroutine tasks (including manual and abstract).

Routine tasks refer to sequential and structured activities based on rules and procedures. They are characteristic of numerous workers, administration, and office tasks, especially manual and clerical jobs, which require moderate skills like bookkeeping, office work, repeated production activities, and work monitoring. Because the key tasks related to these activities must strictly adhere to specific procedures, they can - and increasingly are - codified in computer software and performed by machines; or, they are electronically commissioned to internal companies, other entities in the business environment, or overseas outlets through outsourcing and offshoring.

Nonroutine tasks include manual and cognitive tasks. Nonroutine manual tasks mainly refer to the ability to adapt manual activities to specific situational changes, including visual and linguistic recognition, direct interaction, and interpersonal and environmental adaptation. Such jobs are not subject to automatization, as it is impossible to present a machine's functioning with multivariate instructions. Moreover, such jobs are not offshored because they must be performed in person and require flexible behavior that depends on situational factors.

Cognitive tasks consist in performing activities based on problem-solving, intuition, persuasion, and creativity; they relate to specialized, managerial, and technical posts in the field of law, medicine, sciences, engineering, design, and management. Efficient employees in such fields are highly educated and possess analytical abilities. These analytical tasks complement computer technology activities, because analytical tasks, problem-solving, and creativity heavily rely on the assessment of input data, the existence of a given problem, and the need for intellect-based considerations. Due to the fact that abstract non-routine tasks require interpersonal or situational adaptability, the task model divides these tasks into analytical and interactive. The former requires advanced problem-solving while the latter interpersonal adaptability. 


\section{Data and Method}

The research study was conducted in one of the municipal enterprises ${ }^{3}$ in Poland, which is a publicly owned Joint Stock Company local service provider. As autonomous organizations owned by municipalities outside of the local bureaucracy, municipal companies have tariffs and commercial revenues to produce and deliver local public services (Voorn et al., 2017, p. 820). Municipal enterprises respect the following principles: accessibility, adaptability, conflict resolution, continuity, equality, participation, transparency, and universality (Marques, 2010). The availability of affordable public services of general economic interest of acceptable quality is a legal requirement (Clifton et al., 2005). In that respect, the studied municipal company is organized as a municipally-owned corporation (MOC). MOCs constituted by the municipality to retain ultimate control through ownership. MOCs typically provide a single service like bus services, water and sewerage services, and refuse collection. MOCs have independent corporate status and are governed by appointed executive boards and usually operating under private law (Voorn et al., 2017). The current study used data obtained in 2009 and 2018. The study sought to:

- identify the changing share of particular types of jobs that represent a diverse level of creativity;

- analyze the individual educational level and experience both total and within the company from the perspective of identified types of positions.

The study gathered data from three major internal sources of information: the scopes of responsibilities of organizational positions, personnel documentation regarding the individual level of education and professional experience (both total and in the enterprise), and the results of interviews with executive staff and employees on particular posts. Similarly, the research procedures were based on different methods, i.e. document analysis, structured interviews, teamwork methods, and classification techniques. Such a research approach was to ensure the internal validity of empirical evidence through observational and interpretational replicability (Stake, 1995). Documentary analysis and structured interviews were employed in the process of collecting information and identifying the individual level of education and professional experience (both total and in the enterprise), along with the factors that determine the degree of

3 Municipal enterprises have several specific characteristics, i.e. 1) they are based on public law institutions (the municipality); 2) Supervisory Board and Chief Executive Officer (CEO) are approved by the municipality; 3 ) they must deliver public service, while private service delivery by municipal enterprises is considered a competition restriction on the market and is not feasible; 4) the municipal enterprise is accountable to the founder (the municipality); 5) depending on the public nature, enterprise revenues and expenses may be fully or partially public; 6) the public enterprise must be transparent, accountable, and employ corporate social responsibility; 7) audit and control of a public enterprise is conducted by the municipality (Narmania, 2018). 
innovativeness and creativity related to particular positions. The remaining methods were used to qualify and analyze assessments and identify particular types of jobs according to adopted classification; i.e. routine manual, nonroutine manual, routine cognitive, and nonroutine cognitive. First, basing upon documents provided by the HR department, the study identified the educational level (Education) and job experience (Experience) of employees, along with two types of jobs: manual and cognitive. Job experience was measured with the number of years in employment, while the Educational level (Education) on a 5-item scale (see Table 1).

Table 1. Educational level

The level of education

$$
\begin{aligned}
& \text { Rank } \\
& 1-\text { low, } 5-\text { high }
\end{aligned}
$$

\begin{tabular}{l|c|}
\hline Elementary, middle school & 1 \\
\hline Basic vocational & 2 \\
\hline Secondary comprehensive & 3 \\
\hline Secondary vocational/technical & \\
\hline Post-secondary & 4 \\
\hline Higher (including BA/BSc) & 5 \\
\hline
\end{tabular}

Source: own elaboration.

The next stage conducted interviews - based on checklists (worksheets) ${ }^{4}$ - with the heads of organizational units and employees in order to gather information on the determinants of the degree of innovation and creativity of organizational positions. Interviews were preceded by a review of the formal scopes of relevant duties. Reviews were conducted in two periods: October-December 2009 and January-March 2018. Interview sheets and the collected organizational documentation (organizational charts, formal job descriptions) were a basis for the next stage conducted by a team of experts (composed of company executives and external experts), focused on the identification of the degree of innovativeness and creativity. These procedures allowed for the assignment of particular organizational posts to one of the four categories of jobs - routine manual, nonroutine manual, routine cognitive, and nonroutine cognitive - which based on the adopted characteristics of particular organizational posts

4 The same checklists were used in studies of 2009 and 2018. The structure of the interview content included: the name of the work post, key job functions, and optional characteristics to be marked, which enabled the diagnosis of the level of innovation of job tasks, as each indication had to be confirmed by a specific example. For instance: "The work is clearly defined by the instructions, work regulations, technological process, supervisor's order," "The work requires independent selection of the implementation variant or method of implementation." 
(see Table 2). Employees who occupied particular organizational positions were then referred to individual educational and experience levels in 2009 and 2018.

Table 2. Description of criteria for grouping organizational posts

\section{Administration and office posts}

Routine cognitive. Simple information-related tasks: organizing, storing, retrieving,

竞 and manipulating information. Moderate level of initiative and ingenuity. Work (activities, operations) based on strict instructions, labor code, technological processes and supervisors' instructions. Routine thinking.

Nonroutine cognitive. Work involves problem-solving, information assessment, and creativity. It requires initiative

흘
and ingenuity. Work involves the interpretation of phenomena and processes, and the adapting of existing solutions to the company's current needs and potential. Research work is required along with the testing of new solutions. Analytical, synthetic, and creative thinking.

\section{Workman posts}

Routine manual. No initiative or creativity required. Work (activities, operations) based on strict instructions, labor code, technological processes, and supervisors' instructions. Routine thinking.

Nonroutine manual. Moderate initiative and ingenuity. Work involves independent choice of implementing techniques. Semi-routine thinking.

Source: own research.

\section{Empirical Results and Discussion}

On the basis of the research, the share of particular types of work in the total number of employees was identified, along with the change in the share of these positions in the analyzed period (see Table 3). In the analyzed period, the share of employees performing routine work decreased, with larger changes recorded in the group of routine manual (from $49.52 \%$ to $16.72 \%$ ) than in routine cognitive work (from $11.52 \%$ to $11.09 \%$ ). Simultaneously, the percentage of nonroutine jobs increases, with larger changes in the workman posts (from about $12 \%$ to about $39 \%$ ) than in the group of administrative and office positions (from around $27 \%$ to about $33 \%$ ). Therefore, we may conclude that in the analyzed period there was an increase in the complexity of work, which required higher levels of creativity from employees. This is especially noticeable in relation to workers' positions. 
Table 3. The share of particular types of jobs in the total number of jobs in the analyzed period (in \%)

\begin{tabular}{|l|c|c|}
\hline \multicolumn{1}{|c|}{ Types of jobs } & \multicolumn{2}{|c|}{ Total } \\
\hline Routine manual & $\mathbf{2 0 0 9}$ & $\mathbf{2 0 1 8}$ \\
\hline Nonroutine manual & 49.52 & 16.72 \\
\hline Routine cognitive & 11.79 & 38.82 \\
\hline Nonroutine cognitive & 11.52 & 11.09 \\
\hline Number & 27.18 & 33.36 \\
\hline
\end{tabular}

Source: own research.

The study also identified that 841 employees in 2018 were employed in 2009 (approx. $74 \%$ ). Intragroup transfers among individual groups of positions in two research periods are included in Table 4.

Table 4. Intragroup transfers among individual groups of positions in two research periods

\begin{tabular}{|c|c|c|c|}
\hline Change (2009-2018) & Number & Percentage & \\
\hline Nonroutine _ cognitive $->$ Nonroutine _ cognitive & 233 & $96.3 \%$ & \multirow{3}{*}{$100.0 \%$} \\
\hline Nonroutine _ cognitive $->$ Routine _ cognitive & 8 & $3.3 \%$ & \\
\hline Nonroutine _ cognitive $->$ Routine _ manual & 1 & $0.4 \%$ & \\
\hline Nonroutine _ manual $->$ Nonroutine _ manual & 90 & $94.7 \%$ & \multirow{2}{*}{$100.0 \%$} \\
\hline Nonroutine _ manual $->$ Routine _ manual & 5 & $5.3 \%$ & \\
\hline Routine _ cognitive $->$ Nonroutine _ cognitive & 61 & $56.0 \%$ & \multirow{2}{*}{$100.0 \%$} \\
\hline Routine _ cognitive $->$ Routine _ cognitive & 48 & $44.0 \%$ & \\
\hline Routine _ manual $->$ Nonroutine _ cognitive & 4 & $1.0 \%$ & \multirow{4}{*}{$100.0 \%$} \\
\hline Routine _ manual $->$ Nonroutine _ manual & 226 & $57.2 \%$ & \\
\hline Routine _ manual $->$ Routine _ cognitive & 5 & $1.3 \%$ & \\
\hline \multirow[t]{2}{*}{ Routine _ manual $->$ Routine _ manual } & 160 & $40.5 \%$ & \\
\hline & 841 & & \\
\hline
\end{tabular}

Source: own research. 
The study also analyzed the change in the level of education and experience of employees in individual job groups in the period under consideration. However, for the needs of the conducted analyses, the basic indicators of descriptive statistics were calculated by referring to the collected empirical material.

Table 5. Descriptive statistics of used variables

\begin{tabular}{|l|l|l|l|l|l|l|l|}
\hline \multicolumn{1}{|c|}{ Variable } & Mean & Median & Min & Max & $\begin{array}{l}\text { Standard } \\
\text { deviation }\end{array}$ & $\begin{array}{l}\text { Coefficient } \\
\text { of variation }\end{array}$ & No. \\
\hline Education & 3.1876 & 3.000 & 1.000 & 5.000 & 1.3848 & 0.4344 & 2309 \\
\hline $\begin{array}{l}\text { Job experience } \\
\text { Total }\end{array}$ & 25.060 & 27.000 & 0.000 & 55.000 & 12.469 & 0.4975 & 2309 \\
\hline $\begin{array}{l}\text { Job experience } \\
\text { within Company }\end{array}$ & 17.042 & 16.000 & 0.000 & 49.000 & 11.440 & 0.6713 & 2309 \\
\hline
\end{tabular}

Source: own elaboration.

Table 5 contains the values of basic descriptive statistics of the analyzed variables in the two analyzed years, i.e. 2009 and 2018. However, Tables 6-8 show the values of statistics in the two periods of analysis by referring to the education and experience of employees in individual job groups.

Table 6. Descriptive statistics of variables used in 2009 and 2018

\begin{tabular}{|c|c|c|c|c|c|c|c|c|c|}
\hline \multirow{2}{*}{ Indicator } & \multicolumn{2}{|c|}{ Mean } & \multirow{2}{*}{$\begin{array}{c}\left.\stackrel{x^{-}}{(2009}=1.00\right) \\
2018\end{array}$} & \multicolumn{2}{|c|}{$\begin{array}{l}\text { Standard } \\
\text { deviation }\end{array}$} & \multicolumn{2}{|c|}{$\begin{array}{l}\text { Coefficient of } \\
\text { variation }\end{array}$} & \multicolumn{2}{|c|}{ Gini coefficient } \\
\hline & 2009 & 2018 & & 2009 & 2018 & 2009 & 2018 & 2009 & 2018 \\
\hline Education & 2.976 & 3.491 & 1.173 & 1.3886 & 1.3815 & 0.4666 & 0.3957 & 0.2345 & 0.2106 \\
\hline $\begin{array}{l}\text { Job } \\
\text { experience } \\
\text { within } \\
\text { Company }\end{array}$ & 16.840 & 17.238 & 1.024 & 10.984 & 11.859 & 0.6522 & 0.6879 & 0.3736 & 0.3928 \\
\hline $\begin{array}{l}\text { Job } \\
\text { experience } \\
\text { Total }\end{array}$ & 25.155 & 24.968 & 0.993 & 11.692 & 13.173 & 0.4648 & 0.5276 & 0.2636 & 0.3034 \\
\hline
\end{tabular}

Source: own elaboration.

In 2009-2018, the average employee education increased by 17\%. Average work experience - measured by work experience in the analyzed company - increased by mere 
2.4\%, accompanied by a slight decrease in employee total work experience (see Table 6). Please note that the greatest diversity was recorded for the values of the variable that reflects work experience in the analyzed entity. Moreover, the values of the coefficient of variation and Gini coefficient indicate that differences in employee education in the analyzed period decrease.

\section{Education and Jobs}

An increase in the average education of all employees in the analyzed period is accompanied by a $26 \%$ increase in the value of this indicator for routine tasks and the simultaneous decrease in education rates (approx. 11\%) for non-routine tasks (see Table 7). The analysis of education levels indicates that the proportion of employees with at least secondary education increases, with the highest increase recorded for employees with university degrees. A similar trend is recorded for routine tasks; unlike in the case of non-routine tasks, which are characterized by a slight increase in the proportion of employees with secondary education and a decrease in the number of employees with post-secondary and higher education (see Figure 1).

Figure 1. Education and types of jobs

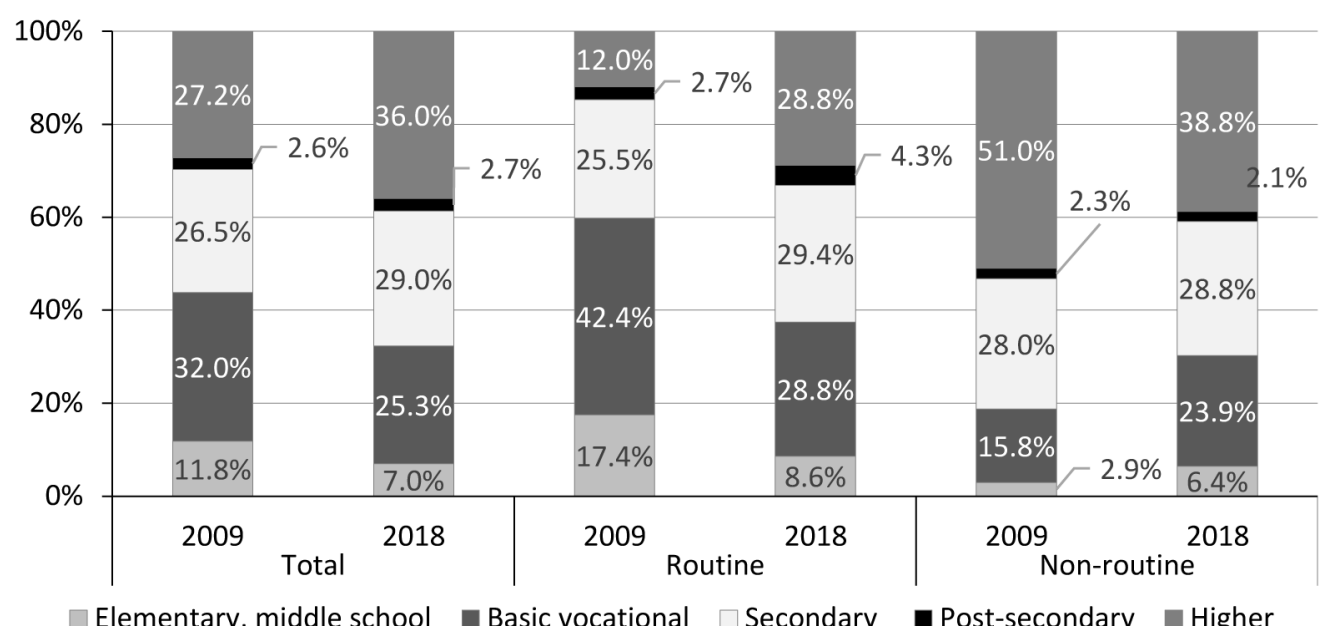

Source: own elaboration.

In general, jobs that require lower creativity (routine tasks) are characterized by increased education levels in the analyzed period, while employees who perform tasks that require greater creativity (non-routine tasks) on average have lower education. This trend can also result from the fact that - in the analyzed period - the company developed a greater complexity of work, measured by higher creativity levels required 
for performing specific tasks. In the analyzed period, both in absolute and relative terms, the number of routine tasks decreased in favor of non-routine work. So, employees previously doing routine work (with relatively lower education levels) then were transferred to perform non-routine tasks. Consequently, the average education levels in this group of employees decreased.

Average education levels of employees who perform all types of tasks in the analyzed period increase, with higher increases recorded for routine tasks (manual - by approx. $10 \%$, cognitive - approx. $7 \%$ ) as compared with non-routine tasks (manual - approx. $6 \%$, cognitive $-2 \%$ ). Overall, non-routine employees are characterized by higher education levels. In the analyzed period, the proportion of workmen who perform routine tasks and have elementary or vocational education decreased, which is accompanied by an increase in the number of employees with at least secondary education (see Figure 2). A similar trend is recorded for non-routine manual tasks, however, with an increase in the proportion of employees with elementary education.

Figure 2. Changes in the share of educational levels in particular types of jobs in 2009 and 2018
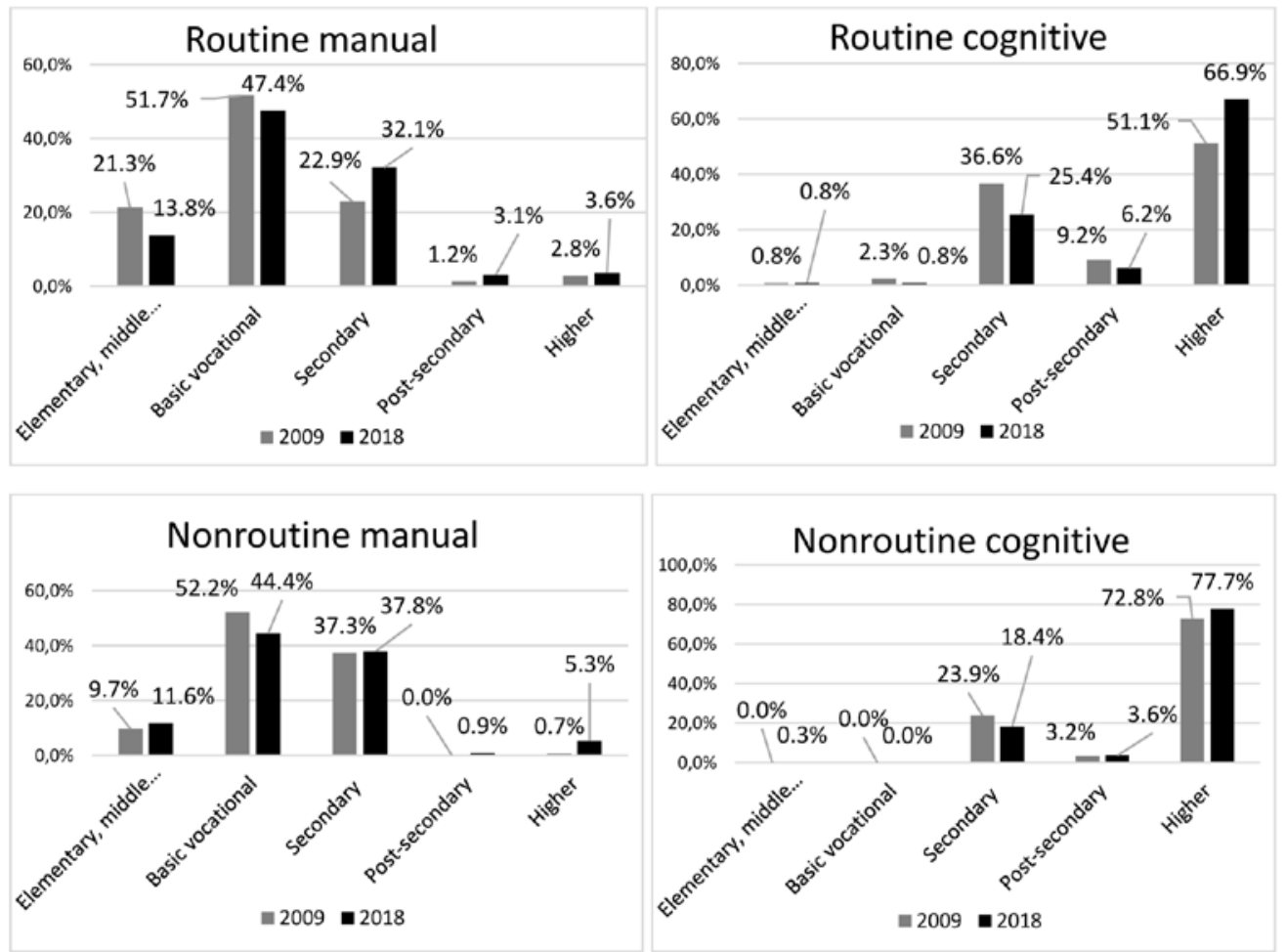

Source: own elaboration. 
In the group of employees who perform cognitive tasks - including both routine and non-routine ones - an overwhelming majority has secondary and higher education, while their proportion in the analyzed period follows a similar trend: a decrease in the proportion of employees with secondary education, accompanied by a greater share of employees with higher education.

Relative differences in education levels measured by standard deviation (Vs) increase for non-routine jobs (0.34-0.4) and decrease for routine tasks (0.47-0.43). Greater differences in education levels (Vs) for non-routine jobs are mainly caused by greater differences (Vs) in the group of employees who perform non-routine manual tasks (0.29-0.37; see Table 7). On the other hand, the use of the differential coefficient based on quartile deviation $(\mathrm{Vq})$ indicates an increase in relative education differences in both groups of employees, i.e. routine (0.25-0.5) and non-routine (0.2-0.5; see Table 7).

\section{Experience and Jobs}

In the analyzed period, average work experience in the company increased in the group of routine jobs (17.79-17.84) and non-routine tasks (15.34-17.02). Average total work experience in the group of routine jobs decreased slightly (25.45-24.69), while it increased for non-routine jobs (24.70-25.03), accompanied by a simultaneous decrease in median Me levels in routine (28-27) and non-routine jobs (27-26). The relative differentiation of experience (total and in the company), measured both by standard (Vs) and quartile deviation (Vq), increased in both groups of jobs. The exception to this trend is recorded for experience differentiation in the analyzed company in the group of non-routine jobs (see Table 7).

Interesting conclusions can be drawn from the comparison of the particular indicators that describe total work experience and work experience in the analyzed company. It turns out that, on average, employees who perform routine jobs join the analyzed company with eight-year professional experience in 2009, and with seven-year experience in 2018. However, the difference in the median of total work experience and the median of work experience in the analyzed company in both periods is ten years. In the case of non-routine jobs, average work experience before joining the company in 2009 is approximately nine years, and in 2018 - approximately eight years. Simultaneously, the difference between the median of total work experience and the median of experience in the analyzed company in 2009 is 14 years, while in 2018 - 11 years (see Table 7).

The highest total work experience levels (more than 26 years) are recorded for manual jobs, including routine (27-30 years) and non-routine jobs (26-29 years). Relatively 
lower total work experience levels are recorded for employees who perform cognitive tasks. However, there appear significant differences in this case: routine workers have the average experience of approximately 16.5 years, while those performing cognitive non-routine tasks of approximately 2.5 years (see Table 8 ). Relatively greater differentiation, measured both by standard and quartile deviation, is recorded for cognitive workers, with the highest levels in routine cognitive tasks. The respectively lower differences in total work experience occur in the group of employees performing manual tasks.

Table 7. Differentiation indexes for education and experience in particular job types

\begin{tabular}{|c|c|c|c|c|c|c|c|}
\hline & \multirow{2}{*}{ Indexes } & \multicolumn{2}{|c|}{ Education } & \multicolumn{2}{|c|}{ Experience } & \multicolumn{2}{|c|}{ Experience in the company } \\
\hline & & 2009 & 2018 & 2009 & 2018 & 2009 & 2018 \\
\hline \multirow{10}{*}{ 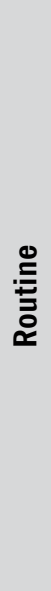 } & $x^{-}$ & 2.49 & 3.16 & 25.45 & 24.69 & 17.79 & 17.81 \\
\hline & $\mathrm{x}^{-}(2009 \mathrm{r} .=1.00)$ & 1.00 & 1.269 & 1.00 & 0.970 & 1.00 & 1.001 \\
\hline & Q1 & 2 & 2 & 18 & 12 & 10 & 6 \\
\hline & Me & 2 & 3 & 28 & 27 & 18 & 17 \\
\hline & Q3 & 3 & 5 & 34 & 37 & 26 & 29 \\
\hline & Q4 & 5 & 5 & 50 & 55 & 44 & 49 \\
\hline & Vs & 0.47 & 0.43 & 0.46 & 0.56 & 0.60 & 0.70 \\
\hline & $\mathrm{Vq}$ & 0.25 & 0.5 & 0.29 & 0.47 & 0.44 & 0.66 \\
\hline & $\max / \min$ & 5 & 5 & $50 / 0$ & $55 / 0$ & $44 / 0$ & $49 / 0$ \\
\hline & Number & 694 & 326 & 694 & 326 & 694 & 326 \\
\hline \multirow{10}{*}{ 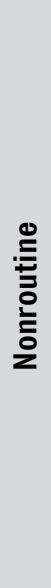 } & $x^{-}$ & 3.83 & 3.43 & 24.70 & 25.03 & 15.34 & 17.02 \\
\hline & $\mathrm{x}^{-}(2009 \mathrm{r} .=100)$ & 1.00 & 0.896 & 1.00 & 1.013 & 1.00 & 1.110 \\
\hline & Q1 & 3 & 2 & 14 & 14 & 6 & 8 \\
\hline & $\mathrm{Me}$ & 5 & 3 & 27 & 26 & 13 & 15 \\
\hline & Q3 & 5 & 5 & 34 & 36 & 23 & 25 \\
\hline & Q4 & 5 & 5 & 49 & 49 & 43 & 48 \\
\hline & Vs & 0.34 & 0.4 & 0.48 & 0.51 & 0.74 & 0.68 \\
\hline & $\mathrm{Vq}$ & 0.2 & 0.5 & 0.37 & 0.42 & 0.65 & 0.57 \\
\hline & $\max / \min$ & 5 & 5 & $49 / 0$ & $49 / 0$ & $43 / 0$ & $48 / 0$ \\
\hline & Number & 443 & 846 & 443 & 846 & 443 & 846 \\
\hline
\end{tabular}

Source: own research. 
Table 8. Differentiation indexes for activity areas and job types in the analyzed period

\begin{tabular}{|c|c|c|c|c|c|c|c|}
\hline & \multirow{2}{*}{ Indexes } & \multicolumn{2}{|c|}{ Education } & \multicolumn{2}{|c|}{ Experience } & \multicolumn{2}{|c|}{ Experience in the company } \\
\hline & & 2009 & 2018 & 2009 & 2018 & 2009 & 2018 \\
\hline \multirow{10}{*}{ 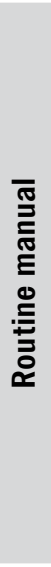 } & $x^{-}$ & 2.126 & 2.352 & 27.485 & 30.3 & 19.188 & 22.5 \\
\hline & $x^{-}(2009 r .=100)$ & 1.00 & 1.106 & 1.00 & 1.102 & 1.00 & 1.173 \\
\hline & Q1 & 2 & 2 & 22 & 24 & 14 & 13 \\
\hline & $\mathrm{Me}$ & 2 & 2 & 29 & 34 & 19 & 25 \\
\hline & Q3 & 3 & 3 & 35 & 39 & 26 & 31 \\
\hline & Q4 & 5 & 5 & 50 & 49 & 43 & 48 \\
\hline & Vs & 0.403 & 0.376 & 0.370 & 0.384 & 0.515 & 0.509 \\
\hline & $\mathrm{Vq}$ & 0.250 & 0.250 & 0.224 & 0.221 & 0.316 & 0.360 \\
\hline & $\max / \min$ & 5 & 5.00 & $50 / 0$ & $49 / 0$ & $43 / 0$ & $48 / 0$ \\
\hline & Number & 563 & 196 & 563 & 196 & 563 & 196 \\
\hline \multirow{10}{*}{ 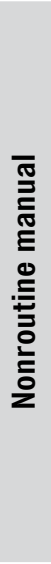 } & $x^{-}$ & 2.29 & 2.44 & 29.80 & 26.84 & 19.13 & 18.13 \\
\hline & $x^{-}(2009$ r. $=100)$ & 1.00 & 1.066 & 1.00 & 0.901 & 1.00 & 0.948 \\
\hline & Q1 & 2 & 2 & 25 & 15 & 12 & 7 \\
\hline & $\mathrm{Me}$ & 2 & 2 & 30 & 30 & 21 & 19 \\
\hline & Q3 & 3 & 3 & 36 & 37 & 26 & 29 \\
\hline & Q4 & 5 & 5 & 44 & 49 & 43 & 47 \\
\hline & Vs & 0.29 & 0.37 & 0.30 & 0.49 & 0.59 & 0.69 \\
\hline & $\mathrm{Vq}$ & 0.25 & 0.25 & 0.18 & 0.37 & 0.33 & 0.59 \\
\hline & $\max / \min$ & 5 & 5 & $44 / 0$ & $49 / 0$ & $43 / 0$ & $47 / 0$ \\
\hline & Number & 134 & 455 & 134 & 455 & 134 & 455 \\
\hline \multirow{10}{*}{ 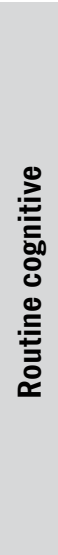 } & $x^{-}$ & 4.08 & 4.38 & 16.69 & 16.43 & 11.80 & 10.71 \\
\hline & $x^{-}(2009$ r. $=100)$ & 1.00 & 1.074 & 1.00 & 0.984 & 1.00 & 0.908 \\
\hline & Q1 & 3 & 3 & 4 & 7 & 3 & 2 \\
\hline & $\mathrm{Me}$ & 5 & 5 & 13 & 13 & 6 & 8 \\
\hline & Q3 & 5 & 5 & 30 & 23 & 21 & 14 \\
\hline & Q4 & 5 & 5 & 44 & 55 & 44 & 49 \\
\hline & Vs & 0.25 & 0.21 & 0.80 & 0.78 & 0.98 & 0.99 \\
\hline & $\mathrm{Vq}$ & 0.20 & 0.20 & 1.00 & 0.61 & 1.50 & 0.73 \\
\hline & $\max / \min$ & 5 & 5 & $44 / 0$ & $55 / 0$ & $44 / 0$ & $49 / 0$ \\
\hline & Number & 131 & 130 & 131 & 130 & 131 & 130 \\
\hline
\end{tabular}




\begin{tabular}{|c|c|c|c|c|c|c|c|}
\hline \multirow{10}{*}{ 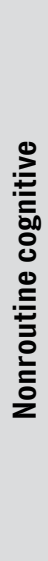 } & $x^{-}$ & 4.49 & 4.59 & 22.49 & 22.91 & 13.71 & 15.72 \\
\hline & $x^{-}(2009$ r. $=100)$ & 1.00 & 1.022 & 1.00 & 1.019 & 1.00 & 1.147 \\
\hline & Q1 & 4 & 5 & 11 & 13 & 6 & 9 \\
\hline & $\mathrm{Me}$ & 5 & 5 & 24 & 21 & 10 & 14 \\
\hline & Q3 & 5 & 5 & 33 & 34 & 19 & 21 \\
\hline & Q4 & 5 & 5 & 49 & 49 & 42 & 48 \\
\hline & Vs & 0.191 & 0.175 & 0.541 & 0.536 & 0.809 & 0.658 \\
\hline & $\mathrm{Vq}$ & 0.100 & 0.00 & 0.458 & 0.5 & 0.650 & 0.429 \\
\hline & $\max / \min$ & 1.67 & 5 & 49 & $49 / 0$ & $42 / 0$ & $48 / 0$ \\
\hline & Number & 309 & 391 & 309 & 391 & 309 & 391 \\
\hline
\end{tabular}

Source: own research.

Relatively longer average work experience is characteristic for manual workers (routine jobs: 19-22.5 years; non-routine jobs; 18-19 years), while shorter work experience in the group of cognitive tasks (routine jobs: approx. 11 years; non-routine jobs: 13-15 years). The analyzed period is characterized by longer average work experience in routine manual jobs (19-22.5 years, i.e. 17\%) and non-routine cognitive tasks (13-15 years, i.e. approx. 15\%). In the remaining groups of employees, average work experience in the company is shorter by approximately 6\% (19-18 years) in non-routine manual jobs and by $10 \%$ (11-10 years) in routine cognitive jobs. The relatively highest differentiation of work experience in the company is recorded for routine cognitive jobs while the lowest for routine manual tasks.

The study examined the change in the content of the work in terms of creativity necessary to fulfill the function of jobs in confrontation with the professional experience and level of education of employees. The results of the conducted research confirm the tendency diagnosed in the literature related to the decrease in the share of routine jobs for non-routine jobs (Autor, 2015; Goos et al., 2009). However, it is difficult to relate to the literature the results of research conducted on the experience and education of employees in connection with the creativity necessary to realize the functions of workplaces.

However, the discussion of the results of the conducted research requires taking into account the specificity of management of municipal enterprises or - generally - public sector entities (Stiglitz and Rosengard, 2015). Although this specificity coincides with the specificity of business organizations in numerous issues (Simon, 1997), many scien- 
tific studies indicate some differences between public and business management (Boyne, 2002; Baarspul, Wilderom, 2011; Ziębicki, 2014). The main difference lies in the greater impact and complexity of the environment on organizations that operate in the public sector. Among such organizations' stakeholders, often with conflicting goals, we may distinguish citizens, economic entities, social organizations, political groups, and state administration bodies (Ziębicki, 2014, p. 121).

The values represented by employees of public entities are less materialistic. However, there is weaker employee involvement than in private businesses. Motivation primarily emerges from non-material factors, such as employment stability and the implementation of tasks of particular importance (Frączkiewicz-Wronka, 2009). Although career paths in the public sector are primarily conditioned by seniority and certificates that confirm specific professional qualifications, there is a growing need for a modified approach; particularly human resources should be considered the basic guarantor of achieving the goals of such organizations (Hondeghem et al., 2005). Hence, the literature suggests that the labor-management relationship should look more after the mutual goals of successful organization and employee satisfaction, along with ex-ante involvement in work design. However, these relations are still oriented on protecting people, lifelong commitment, conflicting goals, antagonistic relationship, and arbitration in individual cases (Berman et al., 2015, p. 19).

\section{Conclusions}

The paper investigates the change in the share of particular types of jobs that require different levels of creativity and differ in the level of education and experience of employees in relation to specific types of jobs in a municipal enterprise in Poland. The study especially aims to capture, first, changes in the number of workplaces with a relative higher level of creative tasks, and second, the extent to which the creativity of workplaces explains employees' education and job experience. Having employed firm-level data, I found that the complexity of work increased in the company. In other words, the research revealed that job functions increasingly required higher levels of creativity from employees, in particular in relation to workers' positions. Moreover, jobs that require higher levels of creativity (non-routine) employees have a relatively higher education. However, their average level of education in the analyzed period decreased as opposed to jobs that require relatively lower levels of creativity (routine). Interesting findings appeared from the analysis of interdependence between creativity and job experience. First, there emerged a relatively shorter average job experience 
(total and in the company) for employees who perform cognitive work. Second, the average job experience increased in the group of employees who perform routine manual and non-routine cognitive work.

The study refers to the job polarization issue by confirming the tendencies of labor markets, which consist of the lowering of the share of routine jobs in favor of the non-routine ones. However, we should note that the literature contains many empirical studies that confirm job polarization in relation to economies ${ }^{5}$ (Terzidis et al., 2017) and sectors (Michaels et al., 2010), with relatively few evidence to confirm this effect at the company level (Heyman 2016), particularly in municipal enterprises. The current study also refers to the potential scope of work process automation (Autor et al., 2003; Acemoglu and Autor, 2011; Terzidis et al., 2017). The results of the current research allow us to conclude that the potential scope of work process automation decreased in the period under scrutiny. In that respect, tendencies diagnosed in the article should be considered as associated with technological progress which, however, was not the subject analyzed in the presented study. Research on technological progress indicates that - along with the use of advanced technologies - routine work becomes increasingly performed by technologies. Hence, the share of routine work among employees reduces in favor of the participation of non-routine work, which requires data analysis and problem-solving. Therefore, future research in the studied municipal enterprise ought to identify the impact of technological progress on the creativity and content of work. Furthermore, future research should attempt explaining to what extent technical progress answers for the diversity in education and experience of employees in the studied enterprise. Moreover, it would be interesting to determine the impact of technical progress on the adaptation of management methods and techniques that guarantee the efficiency of the municipal enterprise management system.

\section{References}

Acemoglu, D. and Autor, D. (2011). Chapter 12 - Skills, Tasks and Technologies: Implications for Employment and Earnings. In: D. Card and O. Ashenfelter (eds.), Handbook of Labor Economics, https://doi.org/10.1016/S0169-7218(11)02410-5.

Acemoglu, D. and Restrepo, P. (2016). The Race Between Machine and Man: Implications of Technology for Growth, Factor Shares and Employment. NBER Working Paper, NBER working paper series, 22252, https://doi.org/10.3386/w22252.

\footnotetext{
5 For instance: the USA (Author et al., 2008; Acemoglu, Author, 2011), Canada (Green, Sand, 2015), Australia (Coelli, Borland, 2016), the UK (Goos, Manning, 2007), Germany (Dustmann et al., 2009), the Netherlands (Terzidis et al., 2017; Van den Berge, ter Weel, 2015), but also in groups of countries, i.e. 16 European economies (Goos et al., 2009), the USA, Japan, and nine European economies (Michaels et al., 2014), and 31 European countries (Wang et al., 2015).
} 
Altenburg, L. (1987). Production Possibilities with a Public Intermediate Good. The Canadian Journal of Economics / Revue Canadienne d'Economique, 20(4), 715-34, https://doi.org/10.2307/135412.

Amabile, T.M. (2012). Componential Theory of Creativity. Harvard Business School Working Paper No. 12-096 (April), https://www.hbs.edu/faculty/Pages/item.aspx?num=42469.

Andersson, Åke E. (2011). Creative People Need Creative Cities. In: D.E. Andersson, Å.E. Andersson and Ch. Mellander (eds.). Handbook of Creative Cities. Cheltenham: Edward Elgar Publishing.

Autor, D.H. and Handel M.J. (2013). Putting Tasks to the Test. Human Capital, Job Tasks and Wages. Journal of Labor Economics, 31(2), 559-596.

Autor, D.H, Katz, L.F. and Kearney, M.S. (2006). The Polarization of the U.S. Labor Market. American Economic Review, 96(2), 189-194.

Autor, D., Levy, F. and Murnane, J. (2003). The Skill Content of Recent Technological Change: An Empirical Exploration. Quarterly Journal of Economics, 118(4), 1279-1333.

Autor, D.H. (2015). Why Are There Still So Many Jobs? The History and Future of Workplace Automation. Journal of Economic Perspectives, 29(3), 3-30, https://doi.org/10.1257/jep.29.3.3.

Baarspul, H.C. and Wilderom, C.P. (2011). Do employees behave differently in public - vs private-sector organizations? Public Management Review, 7(13).

Barbot, B., Besancon, M. and Todd, I.L. (2011). Assessing Creativity in the Classroom. The Open Education Journal, 4(1), 58-66, https://doi.org/10.2174/1874920801104010058.

Batey, M. (2012). The Measurement of Creativity: From Definitional Consensus to the Introduction of a New Heuristic Framework. Creativity Research Journal, 24(1), 55-65, https://doi.org/10.1080/10400419.2012.649181.

Berman, E.M., Bowman, J.S., West, J.P. and Van Wart, M.R. (2015). Human resource management in public service - paradoxes, processes and problems. London: Sage Publications.

Berge van den, W. and Weelter, W. (2015). Baanpolarisatie in Nederland. CPB Policy Brief. CPB Netherlands Bureau for Economic Policy Analysis, The Hague.

Blaschke, M., Cigaina, M., Riss, U.V. and Shoshan, I. (2017). Designing Business Models for the Digital Economy. In: G. Oswald and M. Kleinemeier (eds.), Shaping the Digital Enterprise: Trends and Use Cases in Digital Innovation and Transformation. Cham: Springer International Publishing. https://doi.org/10.1007/978-3-319-40967-2_6.

Blau, F.D. and Kahn, L.M. (2001). Do Cognitive Test Scores Explain Higher US Wage Inequality? NBER Working Paper No. 8210. Cambridge.

Bode, E. and Villar, L.P. (2017). Creativity, Education or What? On the Measurement of Regional Human Capital. Papers in Regional Science, 96(S1), S51-67, https://doi.org/10.1111/pirs.12180.

Boschma, R.A. and Fritsch, M. (2009). Creative Class and Regional Growth: Empirical Evidence from Seven European Countries. Economic Geography, 85(4), 391-423, https://doi.org/10.1111/j.1944-8287.2009.01048.x.

Boyne, G.A. (2002). Public and private management: what's the difference? Journal of Management Studies, 1(39).

Bravermann, H. (1998). Labor and monopoly capita. The degradation or work in the twentieth century. New York: Monthly Review Press.

Brown, A.W., Fishenden, J. and Thompson, M. (2014). Digitizing Government. Understanding and Implementing New Digital Business Models. London: Palgrave Macmillan UK. https://doi.org/10.1057/9781137443649.

Brynjolfsson, E. and McAfee, A. (2014). The Second Machine Age: Work, Progress, and Prosperity in a Time of Brilliant Technologies. WW Norton \& Company. 
Cawley, J., Heckman, J. and Vytlacil, E. (2001). Three Observations on Wages and Measured Cognitive Ability. Labour Economics, 8(4), 419-42, https://doi.org/10.1016/S0927-5371(01)00039-2.

Clifton, J., Comín, F. and Fuentes, D.D. (2005). Empowering Europe’s Citizens’? Public Management Review, 7(3), 417-443, https://doi.org/10.1080/14719030500181052.

Coelli, M. and Borland, J. (2016). Job Polarisation and Earnings Inequality in Australia. Economic Record, 92(296), 1-27.

Deming, D.J. (2017). The Growing Importance of Social Skills in the Labor Market, The Quarterly Journal of Economics, 132(4), 1593-1640, https://doi.org/10.1093/qje/qjx022.

Devroye, D. and Freeman, R.B. (2001). Does Inequality in Skills Explain Inequality of Earnings Across Advanced Countries?, NBER Working Paper No. 8140. Cambridge.

Donegan, M., Drucker, J., Goldstein, H., Lowe, N. and Malizia, E. (2008). Which Indicators Explain Metropolitan Economic Performance Best? Traditional or Creative Class. Journal of the American Planning Association, 74(2), 180-95, https://doi.org/10.1080/01944360801944948.

Dustmann, C., Ludsteck, J. and Schonberg, U. (2009). Revisiting the German Wage Structure. The Quarterly Journal of Economics, 124(2), 843-881.

Florida, R. (2002). The Economic Geography of Talent. Annals of the Association of American Geographers, 92(4), 743-55, https://doi.org/10.1111/1467-8306.00314.

Florida, R. (2014). The Creative Class and Economic Development. Economic Development Quarterly, 28(3), 196-205, https://doi.org/10.1177/0891242414541693.

Frączkiewicz-Wronka, A. (ed.) (2009). Zarzq̨dzanie publiczne - element teorii i praktyki. Katowice: Wydawnictwo Akademii Ekonomicznej w Katowicach.

Funke, J. (2009). On the Psychology of Creativity. In: P. Meusburger, J. Funke and E. Wunder (eds.), Milieus of Creativity: An Interdisciplinary Approach to Spatiality of Creativity. Dordrecht: Springer Netherlands, https://doi.org/10.1007/978-1-4020-9877-2_2.

Gabe, T.M. and Abel, J.R. (2011). Human Capital and Economic Activity in Urban America. Regional Studies, 45(8), 1079-1090.

Glaeser, E.L., Kolko, J. and Saiz, A. (2001). Consumer City. Journal of Economic Geography, 1(1), 27-50, https://doi.org/10.1093/jeg/1.1.27.

Godin, B. (2006). The Knowledge-Based Economy: Conceptual Framework or Buzzword? The Journal of Technology Transfer, 31(1): 17-30, https://doi.org/10.1007/s10961-005-5010-x.

Goos, M. and Manning, A. (2007). Lousy and Lovely Jobs. The Rising Polarization of Work in Britain, The Review of Economics and Statistics, 89(1), 118-133.

Goos, M., Manning, A. and Salomons, A. (2009). Job Polarization in Europe. American Economic Review, 99(2), 58-63.

Green, D.A. and Sand, B.M. (2015). Has the Canadian Labor Market Polarised? Canadian Journal of Economics, 48(2).

Guilford, J.P. (1950). Creativity. American Psychologist, 5(9), 444-454, https://doi.org/10.1037/h0063487.

Hanushek, E. and Woessmann, L. (2009). Do Better Schools Lead to More Growth? Cognitive Skills, Economic Outcomes, and Causation. NBER Working Papers No. 14633. Cambridge.

Heckman, J.J., Humphries, J.E., Veramendi, G. and Urzua, S.S. (2014). Education, Health and Wages. 19971. National Bureau of Economic Research.

Heckman, J.J., Stixrud, J. and Urzua, S. (2006). The Effects of Cognitive and Noncognitive Abilities on Labor Market Outcomes and Social Behavior. Journal of Labor Economics, 24(3), 411-482, https://doi.org/10.1086/504455.

Heyman, F. (2016). Job Polarization, Job Tasks and the Role of Firms. IFN Working Paper 1123. Stockholm: Research Institute of Industrial Economics (IFN), http://hdl.handle.net/10419/175060. 
Hondeghem, A., Horton, S. and Scheepers, S. (2005). Modèles de gestion des competences en Europe. Revue française d'administration publique, 16, 561-576.

Kremer, M. and Maskin, E. (1996). Wage Inequality and Segregation by Skill. Working Paper no. 5718, National Bureau of Economic Research, Cambridge.

Kupczyk, T. (2014). Competencies of Management Staff in the knowledge-based economy. Wrocław: Wyższa Szkoła Handlowa.

Lemons, G. (2011). Diverse Perspectives of Creativity Testing: Controversial Issues When Used for Inclusion Into Gifted Programs. Journal for the Education of the Gifted, 34(5), 742-772, https://doi.org/10.1177/0162353211417221.

Leuven, E., Oosterbeek, H. and van Ophem, H. (2004). Explaining International Differences in Male Skill Wage Differentials by Differences in Demand and Supply of Skill. Economic Journal, 114(495), 466-486.

Machin, S. and Van Reenan, J. (1998). Technology Changes in Skill Structure: A Review of Recent Trends and Proposed Explanations. Quarterly Journal of Economics, 113, 1215-1279.

Manyika, J., Chui, M., Miremadi, M., Bughin, J., George, K., Willmott, P. and Dewhurst, M. (2017). A Future That Works: Automation, Employment, and Productivity, McKinsey Global Institute, www.mckinsey.com/featured-insights/digital-disruption/mgi.

Markusen, A. (2004). Targeting Occupations in Regional and Community Economic Development. Journal of the American Planning Association, 70(3), 253-268, https://doi.org/10.1080/01944360408976377.

Marlet, G. and van Woerkens, C. (2004). Skills and Creativity in a Cross-Section of Dutch Cities. Discussion Paper Series/Tjalling C. Koopmans Research Institute 04 (29), http://dspace.library.uu.nl/handle/1874/7392.

Marques, R.C. (2010). Regulation of Water and Wastewater Services. An International Comparison. London, UK: IWA Publishing.

Marrocu, E. and Paci, R. (2012). Education or Creativity: What Matters Most for Economic Performance? Economic Geography, 88(4), 369-401, https://doi.org/10.1111/j.1944-8287.2012.01161.x.

Mcgranahan, D. and Wojan, T. (2007). Recasting the Creative Class to Examine Growth Processes in Rural and Urban Counties. Regional Studies, 41(2), 197-216, https://doi.org/10.1080/00343400600928285.

Mellander, Ch. and Florida, R. (2011). Creativity, Talent, and Regional Wages in Sweden. The Annals of Regional Science, 46(3), 637-660, https://doi.org/10.1007/s00168-009-0354-z.

Michaels, G., Natraj, A. and Van Reenen, J. (2010). Has ICT polarized skill demand? Evidence from eleven countries over 25 years, National Bureau of Economic Research, Working Paper 16138, Cambridge.

Michaels, G., Natraj, Ash. and van Reenen, J. (2014). Has ICT polarized skill demand? Evidence from eleven countries over twenty - five years. The Review of Economics and Statistics, 96(1), 60-77.

Narmania, D. (2018). Efficient Management of Municipal Enterprises. European Journal of Multidisciplinary Studies, 7(2).

OECD (2016). Meeting the policy challenges of tomorrow's digital economy, www.oecd.org/internet/ministerial.

OECD (2017). Getting Skills Right: Skills for Jobs Indicators. Getting Skills Right. Paris: OECD Publishing, https://doi.org/10.1787/9789264277878-en.

Pi, J. and Zhang, P. (2018). Skill-Biased Technological Change and Wage Inequality in Developing Countries. International Review of Economics \& Finance, 56, 347-362,

https://doi.org/10.1016/j.iref.2017.11.004. 
Runco, M.A. and Jaeger, G.J. (2012). The Standard Definition of Creativity. Creativity Research Journal, 24(1), 92-96, https://doi.org/10.1080/10400419.2012.650092.

Said-Metwaly, S., Van den Noortgate, W. and Kyndt, E. (2017). Approaches to Measuring Creativity: A Systematic Literature Review. Creativity. Theories - Research - Applications, 4(2), https://doi.org/10.1515/ctra-2017-0013.

Shapiro, J.M. (2006). Smart Cities: Quality of Life, Productivity, and the Growth Effects of Human Capital. The Review of Economics and Statistics, 88(2), 324-335, https://doi.org/10.1162/rest.88.2.324.

Simon, H.A. (1997). Administrative behavior-a study of decision-making processes in administrative organizations. New York: Macmillan.

Snow, Ch.C., Fjeldstad, Ø.D. and Langer, A.M. (2017). Designing the Digital Organization. Journal of Organization Design, 6(1), https://doi.org/10.1186/s41469-017-0017-y.

Stake, R.E. (1995). The Art of Case Study Research. Thousand Oaks, California: Sage Publications.

Stiglitz, J.E. and Rosengard, J.K. (2015). Economics of the Public Sector. New York: W.W. Norton \& Company.

Suga, N. and Tawada, M. (2007). International Trade with a Public Intermediate Good and the Gains from Trade. Review of International Economics, 15(2), 284-93, https://doi.org/10.1111/j.1467-9396.2007.00648.x.

Tawada, M. and Abe, K. (1984). Production Possibilities and International Trade with a Public Intermediate Good. The Canadian Journal of Economics / Revue Canadienne d'Economique, 17(2), 232-48, https://doi.org/10.2307/134955.

Terzidis, N., van Maarseveen, R., Ortega-Argiles, R. (2017). Employment polarization in local labor markets: The Dutch case, CPB Netherlands Bureau for Economic Policy Analysis, CPB Discussion Paper No. 358, November.

Tomczyk-Horyń, K. and Knosala, R. (2014). Evaluation of employee creativity in the context of production accounting system. Technical Transaction Mechanics, 2-M, 65-73.

Voorn, B., van Genugten, M.L. and van Thiel, S. (2017). The Efficiency and Effectiveness of Municipally Owned Corporations: A Systematic Review. Local Government Studies, 43(5), 820-841, https://doi.org/10.1080/03003930.2017.1319360.

Wang, J., Caminada, K., Goudswaard, K. and Wang, Ch. (2015). Decomposing Income Polarization and Tax - Benefit Changes Across 31 European Countries and Europe Wide, 2004-2012, Leiden University, Department of Economics.

Ziębicki, B. (2014). Efektywność organizacyjna podmiotów sektora publicznego. Kraków: Wydawnictwo Uniwersytetu Ekonomicznego w Krakowie.

Zhou, J. and Hoever, I.J. (2014). Research on Workplace Creativity. A Review and Redirection, The Annual Review of Organizational Psychology and Organizational Behavior, 1, 333-359, https://doi.org/10.1146/annurev-orgpsych-031413-091226. 